\title{
Ovarian, metabolic and endocrine indexes in dairy cows with different body condition scores
}

\author{
A.V. Sirotkin ${ }^{1,4}$, A.V. Makarevich ${ }^{1,2}$, P. Makovicky ${ }^{3}$ and E. Kubovicova ${ }^{1,2}$ \\ ${ }^{1}$ Animal Production Research Centre Nitra \\ Hlohovecka 2, 95141 Lužianky-near-Nitra, Slovak Republic \\ ${ }^{2}$ Research Institute for Cattle Breeding Ltd. Rapotin \\ Vyzkumniku 267, 78813 Vikyrovice, Czech Republic \\ ${ }^{3}$ Czech University of Life Sciences in Prague, Department of Veterinary Sciences \\ 16521 Prague 6 - Suchdol, Czech Republic
}

KEY WORDS: cattle, emaciation, body condition score, ovaries, metabolism, hormones
Received: 12 June 2013

Revised: 3 September 2013

Accepted: 11 October 2013

\footnotetext{
${ }^{4}$ Corresponding author: e-mail: sirotkin@cvzv.sk
}

ABSTRACT. Body condition can influence bovine fertility, but the morphological, biochemical and endocrine mechanisms of this influence are not fully understood. The aim of the study was to examine the interrelationships between cow body condition, morphological and endocrine state of the ovary, and blood metabolic indexes. Czech Fleckvieh dairy cows at the follicular phase of the ovarian cycle and with a tendency towards emaciation (body condition scoreCS2) and cows with an average body condition score (BCS3) were compared. Plasma concentrations of aspartate aminotransferase (AST), non-esterified fatty acids (NEFAs), $\mathrm{Ca}^{2+}$, inorganic phosphorus $\left(\mathrm{P}_{\mathrm{i}}\right), \mathrm{Mg}^{2+}, \mathrm{Fe}^{2+}, \mathrm{Cu}^{2+}, \mathrm{Zn}^{2+}$ (determined using photometrically), leptin and insulin (ELISA), ovarian area, number of visible ovarian follicles, diameter of primary and secondary ovarian follicles and corpora albicantia (macro- and micrometric analysis of ovarian histological sections), as well as the release of progesterone, testosterone, oestradiol and insulin-like growth factor I (IGF-I) by isolated ovarian granulosa cells (RIA) were analysed. No significant differences between BCS2 and BCS3 cows in blood metabolic and endocrine indexes (except for decreased $\mathrm{Zn}^{2+}$ in BCS3 cows) were found. The ovaries of BCS2 cows, however, showed a lower ovarian area, diameter of both primary and secondary follicles and corpora albicantia, but not the number of visible secondary follicles as compared with BCS3 cows. No differences between the release of progesterone, testosterone and IGF-I by ovarian granulosa cells isolated from BCS2 or BCS3 cows were found, but the granulosa cells of BCS2 animals released more oestradiol than those of BCS3 cows. These results indicate that a slight reduction in BCS (tendency towards emaciation) does not substantially affect ovarian secretory activity or metabolic blood indexes. On the other hand, a tendency towards emaciation is associated with reduced ovarian follicle growth (but not their number) and increased secretion of oestradiol. These observations suggest that a tendency towards emaciation can suppress bovine fertility via alterations in ovarian folliculogenesis and oestrogen release. 


\section{Introduction}

Understanding the mechanisms and mediators of the effect of energy metabolism on reproduction can be important for control of both human and animal reproduction. Furthermore, such mediators could be useful for the welfare and selection of animals with a desirable metabolic and reproductive status for animal production. Metabolic state can exert both positive and negative effects on animal reproduction (Hernandez-Medrano et al., 2012). Cows can be a good model to study the link between reproduction, endocrine system, metabolism, and body condition in females. For example, a negative energy balance in post-partum cows causes rapid body weight loss, increased occurrence of metabolic disorders, changes blood levels of glucose, insulin and IGF-I, which are important factors of ovarian functions (Spicer and Echternkamp, 1995; Zulu et al., 2002; Roche et al., 2009; Jackson et al., 2011; Kawashima et al., 2012; Wathes, 2012). A negative energy balance in such cows may restrict the pulsatile release of gonadotropin-releasing hormone, its downstream targets, gonadotropins (FSH and LH), responsiveness of ovarian tissue to gonadotropins and, therefore, adversely affect normal ovarian follicle development, causing follicle atresia (Butler, 2000; Wathes et al., 2007; Hernandez-Medrano et al., 2012). Several studies indicate that a negative energy balance in early lactation can also cause excessive mobilization of fatty acids in the cow's liver tissue. Such cows are less fertile, have significantly longer interval to calving, and a greater number of inseminations per conception compared with cows with moderate fattening (Reid and Collins, 1980; Jackson et al., 2011; Wathes, 2012).

The body condition of dairy cows, evaluated by visual estimation of the body condition score (BCS), influences their reproductive characteristics, i.e. time of oestrus onset, conception, pregnancy and embryo mortality rate (Silke et al., 2002; Roche et al., 2009) probably due to changes in the cell apoptosis rate (Wathes, 2012), ovarian follicular atresia (Pivko et al., 2012), and/or the risk of uterine disorders (Wathes et al., 2007; Roche et al., 2009; Wathes, 2012). A BCS either above or below the 2.75-3.25 range is associated with reduced fertility in both dairy and beef cows (Wathes et al., 2007; Crowe, 2008; Roche et al., 2009). Nevertheless, the biochemical mechanisms and signs of BCS, as well as the association between BCS and endocrine or reproductive functions, have been insufficiently studied. Reproductive functions can be regulated by nutrients (Roche et al., 2009; Hernandez-Medrano et al., 2012) which, in turn, affect metabolic hormones (insulin, leptin), growth factors (insulin-like growth factor I, IGF-I and its binding proteins), GnRH/gonadotropins, steroid hormones, and response to these signalling molecules regulating ovarian folliculogenesis (Webb and Campbell, 2007; Sirotkin, 2011; Hernandez-Medrano et al., 2012; Wathes, 2012). On the other hand, no comparison of the concentrations of these substances in cows of different BCS has been performed previously. It remains to be studied whether BCS can be associated with specific blood indexes of protein, lipid and mineral metabolism, metabolic hormone levels, ovarian folliculogenesis and secretion of ovarian hormones.

The aim of our study was to compare ovarian, metabolic, and endocrine indexes in cows with a tendency towards emaciation (BCS2) and with an average body condition score (BCS3). The animals with BCS2 and BCS3 scores represent the majority of the dairy cow population in the world (Crowe, 2008; Roche et al., 2009).

\section{Material and methods}

\section{Biological material}

The ovaries of cyclic Czech Fleckvieh dairy cows at different times during the post-partum period were recovered at slaughterhouses located in North Moravia (Czech Republic). Manipulations with animals were performed in agreement with local and EU ethical regulations. Cyclic cows were identified on the basis of visual inspection of the ovaries (the presence of developing follicles with a cavity and corpora lutea). The ovaries selected for analysis were at the luteal phase of the ovulatory cycle, which was determined according to the presence of corpora lutea. Only cows with no pathological lesions on sexual organs were selected, identified and kept under a normal feed regime at 8 local farms before slaughter. The animals were assigned to certain grades of BCS according to a 5-point scale (Edmonson et al., 1989; Roche et al., 2009). In our experiments only dairy cows of BCS2 (tendency towards emaciation, $\mathrm{n}=27$ ) and BCS3 (average body condition, $\mathrm{n}=32$ ) were available. Data on groups of these cows were taken from the farm records of individual cows and are presented in Table 1. No data concerning the previous reproductive efficiency of the studied animals were available.

Before slaughter, blood was collected by a syringe, transferred into heparinized tubes, centrifuged at $400 \mathrm{~g}$, and the separated plasma was fro- 
Table. 1. Zootechnical characteristics of dairy cows used in the experiments

\begin{tabular}{lllll}
\hline BCS & Age, & Milk yield, & $\begin{array}{l}\text { Post-partum } \\
\text { period, months }\end{array}$ & $\begin{array}{l}\text { Body weight, } \\
\text { group }\end{array}$ \\
year & $\mathrm{kg}$ & $775 \pm 26$ \\
\hline BCS2 & $4.1 \pm 0.54$ & $7937.3 \pm 434.4$ & $7.8 \pm 1.1$ & $575 \pm 26$ \\
BCS3 & $4.7 \pm 0.67$ & $7744.0 \pm 278.7$ & $8.5 \pm 1.2$ & $648 \pm 37^{*}$ \\
\hline
\end{tabular}

the values are means \pm SEM; ${ }^{*}$ significant $(P<0.05)$ difference between the groups

zenat $-18^{\circ} \mathrm{C}$ for further analyses. Thereafter, the animals were killed by electroshock; their ovaries were collected in PBS solution and transported to the laboratory at ambient temperature for subsequent processing. After measurement of ovarian area and counting the visible ovarian follicles on the ovarian surface, halves of each ovary were used for histological analysis, while the remaining 1.5 of the ovaries were used for granulosa cell isolation and further culture.

\section{Histological analyses}

For histological analysis, ovarian samples were fixed in 10\% neutral buffered formalin (SigmaAldrich Corp., St. Louis, MO, USA). The samples were processed by standard histological procedures. All of the samples were dehydrated in a graded series of ethanol solutions $(70 \%$ and $96 \%$ for $2 \mathrm{~h}$, and $100 \%$ for $1 \mathrm{~h}$ ) and embedded in Technovit 7100 resin (Heraeus GmbH, CoKG, Werheim/Ts., Germany) according to the producer's instructions. For light microscopy, 3-5 $\mu \mathrm{m}$-thick sections were cut using an AC-820 rotation microtome (American Corporation, USA) and placed on standard microslides (Bamed, Ceske Budejovice, Czech Republic). The sections were stained with haematoxylin-eosin. Stained sections were mounted onto Entelan and analysed under a Jenaval light microscope (Carl Zeiss, Jena, Germany).

The identification, classification, and counting of primary and secondary ovarian follicles and of corpora albicantia were performed by using methods described previously (Pedersen and Peters, 1968; Diagone et al., 2008). The number of follicles examined in one section varied from 0 to 28 per section. Primary ovarian follicles were distinguished from secondary ones according to the number of granulosa cell layers. The size of ovarian structures (primary and secondary follicles and corpora albicantia) was determined using an ocular-micrometer (Carl Zeiss). The sizes of tertiary/ preovulatory follicles and corpora lutea were not measured because they represent a stage of the oestrous cycle rather than the general quantitative characteristics of ovarian functions. The presence of primary, secondary and tertiary ovarian follicles, corpora lutea and corpora albicantia is documented in Figure 1.

\section{Cell culture}

The content of secondary ovarian follicles (2-5 $\mathrm{mm}$ in diameter) was aspirated and a suspension of granulosa cells was isolated by repeated ( 3 times) centrifugation $(200 \mathrm{~g}, 10 \mathrm{~min})$ and pipetting in a fresh incubation medium, DMEM/F-12 1:1 mixture (Sigma) supplemented with $10 \%$ foetal bovine serum (Gibco BRL) and 1\% antibiotic-antimycotic solution (Sigma, St. Louis, USA). Granulosa cells $\left(10^{6}\right.$ cells $\left.\cdot \mathrm{ml}^{-1}\right)$ were cultured in $2 \mathrm{ml}$ of culture medium in Falcon 24-well plates (Becton Dickinson, Lincoln Park, USA). All cells were precul-
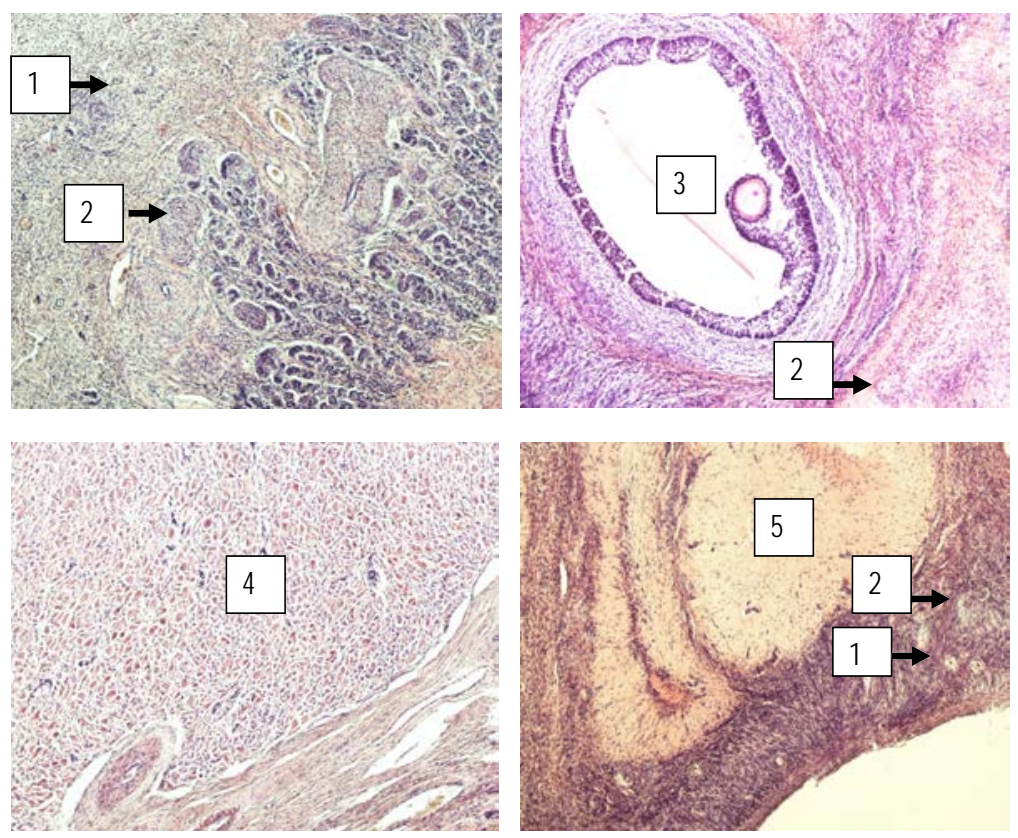

Figure 1. Bovine ovarian structures (histological preparations, magnification $\times 50$ ). 1 - primary follicle; 2 - secondary follicle; 3 - tertiary follicle; 4 - corpora lutea; 5 - corpora albicantia 
Table 2. Methods of substances analysis in cow blood plasma and ovarian granulosa cell culture medium, used analytical kits and their basic characteristics

\begin{tabular}{|c|c|c|c|c|c|}
\hline Substance analysed & $\begin{array}{l}\text { Method } \\
\text { of analysis }\end{array}$ & $\begin{array}{l}\text { Manufacturer, } \\
\text { kit, catalogue number }\end{array}$ & $\begin{array}{l}\text { Sensitivity } \\
\text { of the assay }\end{array}$ & $\begin{array}{l}\text { Intra-assay } \\
\text { coefficient } \\
\text { of variation }\end{array}$ & $\begin{array}{l}\text { Inter-assay } \\
\text { coefficient } \\
\text { of variation }\end{array}$ \\
\hline $\begin{array}{l}\text { Aspartat aminotransferase } \\
\text { (AST) }\end{array}$ & Photometry & $\begin{array}{l}\text { BioVendor Laboratorni Medicina a.s., Prague, } \\
\text { Czech republic, GOT, } 10352\end{array}$ & $0.015 \mu \mathrm{kat} \cdot \mathrm{l}^{-1}$ & $<0.7 \%$ & $<1.6 \%$ \\
\hline $\begin{array}{l}\text { Non-esterified fatty acids } \\
\text { ( NFFA) }\end{array}$ & Photometry & $\begin{array}{l}\text { WAKO Chemicals GmbH, Neuss, Germany, } \\
\text { NEFA-HR(2) R2, 436-91995 }\end{array}$ & $0.01 \mathrm{mmol} \cdot \mathrm{l}^{-1}$ & $<1.5 \%$ & $<1 ., 5 \%$ \\
\hline $\mathrm{Ca}^{2+}$ & Photometry & $\begin{array}{l}\text { BioVendor Laboratorni Medicina a.S., Prague, } \\
\text { Czech Republic, Arsenazo III, } 12101\end{array}$ & $0.005 \mathrm{mmol} \cdot \mathrm{l}^{-1}$ & $<0.8 \%$ & $<3.9 \%$ \\
\hline Inorganic phosphorus $\left(\mathrm{Pi}^{2+}\right)$ & Photometry & $\begin{array}{l}\text { BioVendor Laboratorni Medicina a.s., Prague, } \\
\text { Czech republic, LFosfor anorganicky, } 12101\end{array}$ & $\left.0.033 \mathrm{mmol} \cdot\right|^{-1}$ & $<0.2 \%$ & $<0.9 \%$ \\
\hline $\mathrm{Mg}^{2+}$ & Photometry & $\begin{array}{l}\text { BioVendor Laboratorni Medicina a.s., Prague, } \\
\text { Czech Republic, LHorcik, } 12402\end{array}$ & $0.01 \mathrm{mmol} \cdot \mathrm{I}^{-1}$ & $<0.9 \%$ & $<1.1 \%$ \\
\hline $\mathrm{Fe}^{2+}$ & Photometry & $\begin{array}{l}\text { BioVendor Laboratorni Medicina a.s., Prague, } \\
\text { Czech Republic, LZelezo Ferozin, } 12962\end{array}$ & $0.2 \mu \mathrm{mol} \cdot \mathrm{l}^{-1}$ & $<0.98 \%$ & $<1.98 \%$ \\
\hline $\mathrm{Cu}^{2+}$ & Photometry & $\begin{array}{l}\text { BioVendor Laboratorni Medicina a.s., Prague, } \\
\text { Czech Republic, LMed, } 12651\end{array}$ & $0.24 \mu \mathrm{mol} \cdot \mathrm{I}^{-1}$ & $<1.57 \%$ & $<2.61 \%$ \\
\hline $\mathrm{Zn}^{2+}$ & Photometry & $\begin{array}{l}\text { BioVendor Laboratorni Medicina a.s., Prague, } \\
\text { Czech Republic, DZinek, } 12901\end{array}$ & $0.30 \mu \mathrm{mol} \cdot \mathrm{I}^{-1}$ & $<1.53 \%$ & $<1.57 \%$ \\
\hline Leptin & ELISA & USCN Life Sci. Inc., Wuhan, China E90084Bo & $6.3 \mathrm{pg} \cdot \mathrm{ml}^{-1}$ & $<10.0 \%$ & $<12.0 \%$ \\
\hline Insulin & ELISA & Mercodia AB, Sweden 10-1201-01 & $0.025 \mathrm{ng} \cdot \mathrm{ml}^{-1}$ & $<6.7 \%$ & $<6.8 \%$ \\
\hline Progesterone & RIA & $\begin{array}{l}\text { Orion Diagnostica Oy, Espoo, Finland, } \\
\text { Spektria progesterone RIA, } 68521\end{array}$ & $0.094 \mathrm{ng} \cdot \mathrm{ml}^{-1}$ & $<3.5 \%$ & $<4.6 \%$ \\
\hline Testosterone & RIA & $\begin{array}{l}\text { Orion Diagnostica Oy, Espoo, Finland, } \\
\text { Spektria testosterone RIA, } 68628\end{array}$ & $0.029 \mathrm{ng} \cdot \mathrm{ml}^{-1}$ & $<3.8 \%$ & $<4.8 \%$ \\
\hline Oestradiol & RIA & $\begin{array}{l}\text { Orion Diagnostica Oy, Espoo, Finland, } \\
\text { Spektria oestradiol sensitive RIA, } 67031\end{array}$ & $1.36 \mathrm{pg} \cdot \mathrm{ml}^{-1}$ & $<2.8 \%$ & $<5.8 \%$ \\
\hline $\begin{array}{l}\text { Insulin-like growth factor I } \\
\text { (IGF-I) }\end{array}$ & RIA & $\begin{array}{l}\text { DIAsource ImmunoAssa, Louvain-la-Neuve, } \\
\text { Belgium, IGF-1-RIA-CT, KIP1588 }\end{array}$ & $3.4 \mathrm{ng} \cdot \mathrm{ml}^{-1}$ & $<1.9 \%$ & $<4.1 \%$ \\
\hline
\end{tabular}

tured in the above medium at $37^{\circ} \mathrm{C}$ under $5 \% \mathrm{CO}_{2}$ in humidified air. After 4 days of preculture the medium was replaced with fresh medium of the same composition. After 2 days of culture, the medium from plate wells was gently aspirated and frozen at $-18^{\circ} \mathrm{C}$ to await hormone concentration assays. After culture, cell number and viability were counted in a haemocytometer after Trypan blue staining. No statistically significant differences in these indexes between control and experimental groups were observed.

\section{Biochemical analyses}

Plasma concentration of markers of protein metabolism (aspartate aminotransferase, AST), lipid metabolism (non-esterified fatty acids, NEFAs), mineral metabolism $\left(\mathrm{Ca}^{2+}\right.$, inorganic phosphorus (Pi), $\mathrm{Mg}^{2+}, \mathrm{Fe}^{2+}, \mathrm{Cu}^{2+}, \mathrm{Zn}^{2+}$, metabolic hormones (leptin and insulin), as well as ovarian area, number of visible ovarian follicles, diameter of primary and secondary ovarian follicles and corpora albicantia were estimated. In addition, the secretion of steroid hormones (progesterone, testosterone, oestradiol) and insulin-like growth factor I (IGF-I) by ovarian granulosa cells isolated from BCS2 and BCS3 cow's ovaries were compared. As a model Czech Fleckvieh dairy cows were used, which have not been studied in this respect yet.
The concentrations of substances in both plasma and ovarian cell culture medium were determined by commercial kits according to the instructions of the manufacturers. The assays used in in vitro experiments were validated for the cell-conditioned medium used. Methods of analysis, kit names, characteristics and manufacturers are summarized in Table 2.

\section{Statistics}

Each experiment was performed on BCS2 $(\mathrm{n}=27)$ and $\operatorname{BCS} 3(\mathrm{n}=32)$ animals in 3 replicates. In each ovary intended for histological analysis, 15 sections of different areas were analysed. Each in vitro experimental group was represented by four culture wells with granulosa cells. The data shown are means of values obtained in these 3 separate experiments performed on separate days using different animals, ovaries, and separate pools of granulosa cells. Significant differences between the experiments were evaluated using oneway ANOVA followed by the Wilcoxon-MannWhitney multiple range test using Sigma Plot 11.0 statistical software (Systat Software, GmbH, Erkrath, Germany). Differences between BCS2 and BCS3 at $P<0.05$ were considered significant. 


\section{Results}

A tendency towards emaciation (BCS2) was associated with an increased concentration of $\mathrm{Zn}^{2+}$ in blood plasma. No significant differences between BCS2 and BCS3 in other blood metabolic and endocrine indexes were found (Table 3 ).

Studies of ovarian macromorphology showed that BCS2 cows have a smaller ovarian area than BCS3 cows (Figure 2a). No substantial differences in the number of visible (probably tertiary) ovarian follicles between the groups were found (Figure $2 b$ ). Measurement of follicular size performed on ovarian sections showed smaller diameters of both primary (Figure 2c) and secondary (Figure 2d)
Table 3. Comparison of blood biochemical and hormonal indexes of BCS2 and BCS3 cows

\begin{tabular}{llcl}
\hline $\begin{array}{l}\text { Parameter, } \\
\text { units }\end{array}$ & BCS2 & BCS3 & $\begin{array}{l}\text { Significance of differ- } \\
\text { ences between BCS2 } \\
\text { and BCS3 }\end{array}$ \\
\hline AST, $\mu \mathrm{kat} \cdot \mathrm{l}^{-1}$ & $2.47 \pm 0.83$ & $2.79 \pm 1.14$ & $\mathrm{NS}$ \\
$\mathrm{NEFA}, \mathrm{mmol} \cdot \mathrm{I}^{-1}$ & $0.52 \pm 0.19$ & $0.65 \pm 0.37$ & $\mathrm{NS}$ \\
$\mathrm{Ca}, \mathrm{mmol} \cdot \mathrm{I}^{-1}$ & $2.20 \pm 0.08$ & $2.21 \pm 0.13$ & $\mathrm{NS}$ \\
$\mathrm{Pi}, \mathrm{mmol} \cdot \mathrm{I}^{-1}$ & $2.42 \pm 0.22$ & $2.60 \pm 0.43$ & $\mathrm{NS}$ \\
$\mathrm{Mg}, \mathrm{mmol} \cdot \mathrm{l}^{-1}$ & $1.03 \pm 0.11$ & $1.02 \pm 0.08$ & $\mathrm{NS}$ \\
$\mathrm{Fe}, \mu \mathrm{mol} \cdot \mathrm{I}^{-1}$ & $22.3 \pm 3.5$ & $21.9 \pm 7.1$ & $\mathrm{NS}$ \\
$\mathrm{Cu}, \mu \mathrm{mol} \cdot \mathrm{I}^{-1}$ & $10.4 \pm 0.6$ & $11.4 \pm 1.1$ & $\mathrm{NS}$ \\
$\mathrm{Zn}, \mu \mathrm{mol} \cdot \mathrm{I}^{-1}$ & $10.7 \pm 1.5$ & $8.4 \pm 0.6$ & $\mathrm{P}<0.05$ \\
Leptin, $\mathrm{ng} \cdot \mathrm{ml}^{-1}$ & $0.89 \pm 0.39$ & $0.73 \pm 0.59$ & $\mathrm{NS}$ \\
\hline
\end{tabular}

The values represent means \pm SEM. Abbreviations are explained in the text; NS - not significant
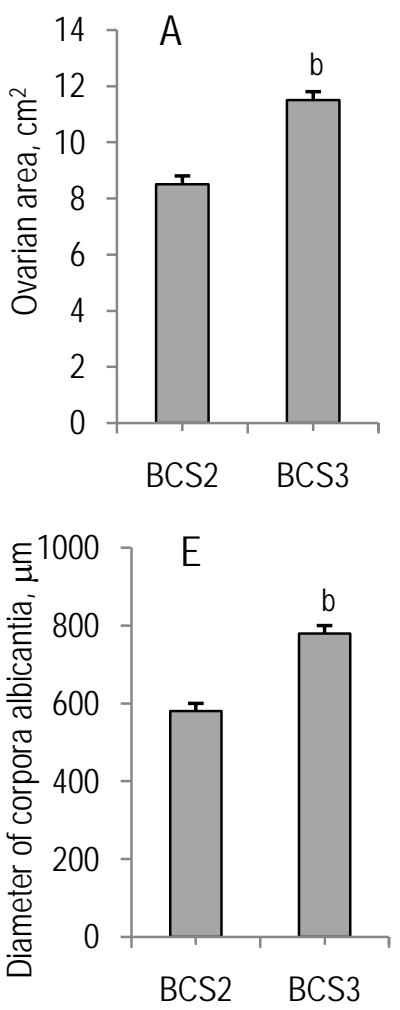
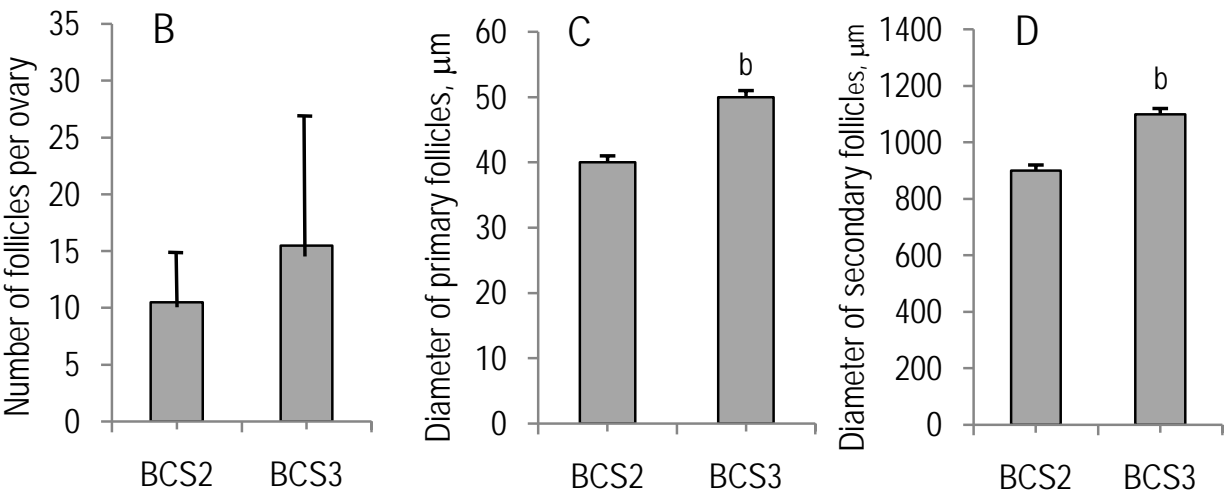

Figure 2. Comparison of ovarian macro- and micromorphological parameters of BCS2 and BCS3 cows. A - ovarian area; B - number of visible ovarian follicles; C - diameter of primary ovarian follicles; D - diameter of secondary ovarian follicles; $\mathrm{E}$ - diameter of corpora albicantia
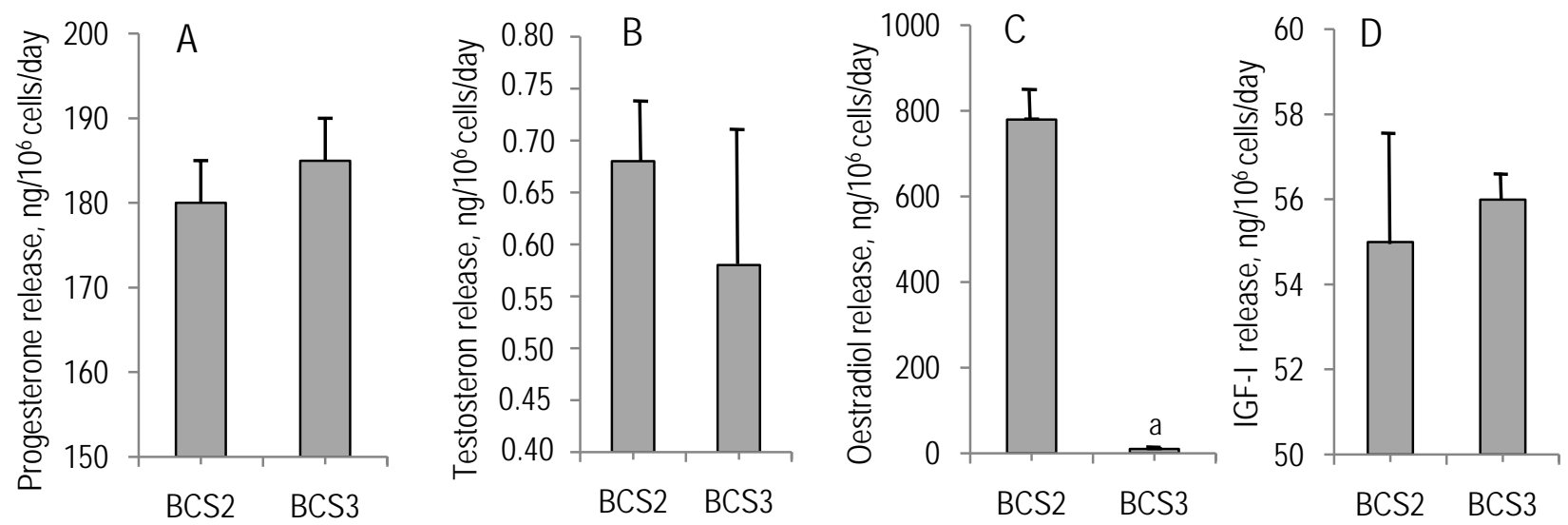

Figure 3. Comparison of hormones release by cultured granulosa cells isolated from ovaries of BCS2 and BCS3 cows: A - progesterone; B - testosteron; C - oestradiol; D - IGF-I 
follicles and the corpora albicantia (Figure 2e) in BCS2 cows in comparison with BCS3 animals.

Secretion of substantial amounts of progesterone, testosterone, oestradiol and IGF-I by cultured granulosa cells isolated from bovine ovaries was found (Figure 3a-d). Comparison of the BCS2 and BCS3 groups showed that granulosa cells isolated from the ovaries of BCS2 cows released more oestradiol than those from the BCS3 group (Figure $3 \mathrm{c})$. No significant differences between the groups in progesterone (Figure 3a), testosterone (Figure. 3b), or IGF-I (Figure 3d) secretion were found.

\section{Discussion}

We found no significant differences between animals from groups BCS2 and BCS3 in blood AST activity, NEFAs, $\mathrm{Ca}^{2+}, \mathrm{P}_{\mathrm{i}}, \mathrm{Mg}^{2+}, \mathrm{Fe}^{2+}, \mathrm{Cu}^{2+}$, leptin and insulin contents, number of visible ovarian follicles, or secretion of progesterone, testosterone and IGF-I by isolated granulosa cells. On the other hand, in our study BCS2 cows (those with a tendency towards emaciation) showed higher plasma $\mathrm{Zn}^{2+}$ concentrations, smaller ovarian area and diameter of both primary and secondary follicles and corpora albicantia. Granulosa cells isolated from their ovaries produced more oestradiol (but not progesterone, testosterone, or IGF-I) than those obtained from BCS3 cows.

The blood biochemistry data is in line with previous reports about no relationships between ovarian functions and plasma AST (Zulu et al., 2002) or NEFA (Kafi and Mirzaei, 2010). However, our observations seems not to be in concert with other reports on negative interrelationships between plasma NEFA (Zulu et al., 2002; Kawashima et al., 2007, 2012; Jackson et al., 2011), insulin (Francisco et al., 2003) and ovarian activity. Here we demonstrate the association between the level of endogenous $\mathrm{Zn}^{2+}$ (but not other microelements) and bovine ovarian functions: BCS2 cows had higher blood $\mathrm{Zn}^{2+}$ levels, lower ovarian, follicular and corpora albicantia size in comparison with the BCS3 animals, while granulosa cells isolated from the ovaries of the former released more oestradiol than those obtained from the BCS3 group. $\mathrm{Zn}^{2+}$ has been shown to be stimulator of appetite (Suzuki et al., 2011) and adipose tissue development (Bing et al., 2010). Therefore, an increased plasma $\mathrm{Zn}^{2+}$ level in cows with a tendency towards emaciation might be a promoter of bovine appetite, fat gain, and return to average BCS. Furthermore, it can not be excluded that plasma $\mathrm{Zn}^{2+}$ can be useful for characterization and prediction of bovine $\mathrm{BCS}$, metabolic and reproductive status.

The morphological data suggest that the tendency towards emaciation in cows can be associ- ated with reduced ovarian follicular growth. This observation corresponds to previous reports demonstrating that BCS2 cows have a greater occurrence of ovarian follicular atresia (Pivko et al., 2012) and a lower fertility rate (Wathes et al., 2007; Crowe, 2008; Roche et al., 2009) than BCS3 cows. Therefore, emaciation-induced reduction in bovine fertility can be due to a higher incidence of atresia and smaller growth of ovarian follicles, although the upstream regulators of this process remain to be elucidated.

The results of our study of isolated ovarian cell secretory activity indicated that the emaciation-induced reduction in follicular growth was not associated with changes in the secretion of progesterone, androgens, or IGF-I, but with an increase in oestrogen release by ovarian cells. The high oestrogen release by BCS2 bovine ovarian cells observed in our study might be considered a sign of decreased follicular atresia, but other potential markers of atresia - androgens and IGF-I (Webb and Campbell, 2007; Sirotkin, 2011) - were not increased in BCS2 cows. Oestrogen can either stimulate or inhibit the pituitary-ovarian axis (Sirotkin, 2011) and synchronize (both increase and decrease) bovine follicular growth (Cavalieri et al., 2006). Therefore, it cannot be excluded that the tendency towards emaciation can suppress bovine ovarian functions via increased oestradiol release. At least, our observations suggest that the tendency towards emaciation is associated with a reduction in ovarian follicular growth and with an increase in ovarian oestrogen release.

In conclusion, our results indicate that in cows, a slight reduction in BCS (tendency towards emaciation) does not substantially affect ovarian secretory activity or metabolic blood indexes. On the other hand, a tendency towards emaciation is associated with reduced ovarian follicle growth and increased release of oestradiol. These observations suggest that a tendency towards emaciation can suppress bovine fertility via alterations in ovarian folliculogenesis and oestrogen release.

\section{Acknowledgements}

This study was supported by the Slovak Research and Development Agency (SRDA; Grant No. APVV0137-10), the Czech National Agency for Agricultural Research (NAZV) (Grant No. QI91A061), and the Ministry of Education, Youth and Sports (MSMT) of the Czech Republic (Grant No. 2678846201).

The authors would like to thank Mrs. Z. Hegedusova and Mr. J. Kubica for the collection of the biological material. 


\section{References}

Bing C., Mracek T., Gao D., Trayhurn P., 2010. Zinc-a2-glycoprotein: an adipokine modulator of body fat mass? Int. J. Obesity 34,1559-1565

Butler W.R., 2000. Nutritional interactions with reproductive performance in dairy cattle. Anim. Reprod. Sci. 60-61, 449-457

Cavalieri J., Hepworth G., Fitzpatrick L.A., Shephard R.W., Macmillan K.L., 2006. Manipulation and control of the estrous cycle in pasture-based dairy cows. Theriogenology $65,45-64$

Crowe M.A., 2008. Resumption of ovarian cyclicity in post-partum beef and dairy cows. Reprod. Domest. Anim. 43, Suppl. 5, 20-28

Diagone K.V., Vicente W.R., Pacheco M.R., Mateus O., 2008. Oocyte morphometry in female dogs (Canis familiaris, Linnaeus, 1758). Anat. Histol. Embryol. 37, 81-85

Edmonson A.J., Lean I.J., Weaver L.D., Farver T., Webster G., 1989 A body condition scoring chart for Holstein dairy cows. J. Dairy Sci. 72, 68-78

Francisco C.C., Spicer L.J., Payton M.E., 2003. Predicting cholesterol, progesterone, and days to ovulation using postpartum metabolic and endocrine measures. J. Dairy Sci. 86, 2852-2863

Hernandez-Medrano J.H., Campbell B.K., Webb R., 2012. Nutritional influences on folliculogenesis. Reprod. Domest. Anim. 4, 274-282

Jackson R.A., Wills J.R., Kendall N.R., Green M.J., Murray R.D., Dobson H., 2011. Energy metabolites in pre- and postpartum dairy cattle as predictors of reproductive disorders. Vet. Rec. 168, 562 (Abstr.)

Kafi M., Mirzaei A., 2010. Effects of first postpartum progesterone rise, metabolites, milk yield, and body condition score on the subsequent ovarian activity and fertility in lactating Holstein dairy cows. Trop. Anim. Health Prod. 42, 761-767

Kawashima C., Sakaguchi M., Suzuki T., Sasamoto Y., Takahashi Y., Matsui M., Miyamoto A., 2007. Metabolic profiles in ovulatory and anovulatory primiparous dairy cows during the first follicular wave postpartum. J. Reprod. Develop. 53, 113-120

Kawashima C., Matsui M., Shimizu T., Kida K., Miyamoto A., 2012. Nutritional factors that regulate ovulation of the dominant follicle during the first follicular wave postpartum in high-producing dairy cows. J. Reprod. Develop. 58, 10-16
Pedersen T., Peters H., 1968. Proposal for a classification of oocytes and follicles in the mouse ovary. J. Reprod. Fertil. 17, 555-557

Pivko J., Makarevich A.V., Kubovicova E., Ostro A., Hegedusová Z., Louda F., 2012: Histopathological alterations in the antral ovarian follicles in dairy cows with a tendency to emaciation. Histol. Histopathol. 27,1211-1217

Reid I.M., Collins R.A., 1980. The pathology of post-parturient fatty liver in high-yielding dairy cows. Invest. Cell Pathol. 3, 237-249

Roche J.R., Friggens N.C., Kay J.K., Fisher M.W., Stafford K.J., Berry D.P., 2009. Invited review: Body condition score and its association with dairy cow productivity, health, and welfare. J. Dairy Sci. 92, 5769-5801

Silke V., Diskin M.G., Kenny D.A., Boland M.P., Dillon P., Mee J.F., Sreenan J.M., 2002. Extent, pattern and factors associated with late embryonic loss in dairy cows. Anim. Reprod. Sci. $71,1-12$

Sirotkin A.V., 2011. Regulators of Ovarian Functions. Nova Science Publishers, Inc., New York. ISBN 978-1-61668-040-4, pp. 194

Spicer L.J., Echternkamp S.E., 1995. The ovarian insulin and insulinlike growth factor system with an emphasis on domestic animals. Domest. Anim. Endocrinol. 12, 223-245

Suzuki H., Asakawa A., Li J.B., Tsai M., Amitani H., Ohinata K., Komai M., Inui A., 2011. Zinc as an appetite stimulator - the possible role of zinc in the progression of diseases such as cachexia and sarcopenia. Recent Pat. Food Nutr. Agric. 3, 226-231

Wathes D.C., Fenwick M., Cheng Z., Bourne N., Llewellyn S., Morris D.G., Kenny D., Murphy J., Fitzpatrick R., 2007. Influence of negative energy balance on cyclicity and fertility in the high producing dairy cow. Theriogenology 68 , Suppl. 1 , S232-S241

Wathes DC., 2012. Mechanisms linking metabolic status and disease with reproductive outcome in the dairy cow. Reprod. Domest. Anim. 47, Suppl. 4, 304-312

Webb R., Campbell B.K., 2007. Development of the dominant follicle: mechanisms of selection and maintenance of oocyte quality. Soc. Reprod. Fertil. Suppl. 64,141-163

Zulu V.C., Sawamukai Y., Nakada K., Kida K., Moriyoshi M., 2002. Relationship among insulin-like growth factor-I, blood metabolites and postpartum ovarian function in dairy cows. J. Vet. Med. Sci. 64, 879-885 